\title{
Review on the genetic history of Algerians within North African populations from the HLA point of view
}

\author{
Abdellatif Moussouni \\ Centre National de Recherches Préhistoriques, Anthropologiques et Historiques (CNRPAH, station de Tlemcen), \\ Algérie, 03, Rue Franklin Roosevelt, Alger 16500 Algérie. . .E-mail:abdellatif.moussouni@gmail.com
}

(Received 27 February 2020; Accepted 3 April 2020; Published 6 June 2020)

\begin{abstract}
This article aims to take stock of knowledge on the history of the human settlement of North Africa and the genetic history of Algerians within North African populations by gathering the most important published results related to HLA allele analysis. These results revealed a strong genetic relationship between studied North African populations (Algeria, Morocco and Tunisia). Such evident genetic affinity between North African populations, also proved by the use of other powerful autosomal markers, agrees with historic data considering North African populations as having similar origins. HLA allele analysis also indicated a genetic link between North African populations (Algeria, Tunisia and Morocco) and the populations of the South-Western Europe particularly the Basques and Spaniards. This would reflect a Neolithic relationship between Iberians and the natives of North Africa (the Berbers). However, other results showed a genetic distinction between samples from North African populations and Middle Eastern populations (Arab-Palestinians, Lebanese's and Jordanians). Beside these results related to Mediterranean populations, the HLA allele variation was analyzed at the world scale showing low genetic differentiations among the three broad continental areas, with no special divergence of Africa.
\end{abstract}

Keywords: Genetic diversity; Molecular Anthropology; Genetic History; HLA genes; North Africa; Algeria. 


\section{History of the human settlement of North Africa}

Due to its geographical location, bordered by the Mediterranean Sea in the North and by the Sahara Desert in the South, North Africa has behaved like an anthropological island on the African continent. Thus the exploration of the genetic history of its populations would be interesting.

Although the ancient human occupation of North Africa is widely documented by archaeological and paleo-anthropological sources, the settlement and evolution of human groups in this area remains poorly understood. This is mainly due to the succession of a large number of prehistoric and historical events that have occurred, notably through two intercontinental migration routes; the Suez Isthmus Canal to the East and the Gibraltar Strait to the West connecting, respectively, this region of the Near East and Europe.

Since Paleolithic times, North Africa has been inhabited by different human groups thought to be linked to early modern humans. In this area in particular, Berbers a term for those people speaking a Berber language (Camps 1980) - is well described since the Capsian (10000 to $4700 \mathrm{BP}$ ). They remained in a vast territory extending from the West to Egypt (oasis of Siouah) and the Sahara Desert to the mountainous regions of the Moroccan Atlas (Coudray et al. 2009). Currently speaking Berber populations live in a dozen African countries, from the Mediterranean to southern Niger, and the Atlantic Near the Nile (Camps 1981).

In historical times, North Africa was an area of turbulence with many ongoing invasions from the East and West, conquests, and attempts at assimilation. Since the end of the ninth century the North African coastline has been occupied respectively by the Phoenicians, Romans, Vandals and Byzantines, their contribution to Berbers, the natives of North Africa, seems to have been limited (Brett and Fentress 1996).This small demographic contribution of these foreigners would be due to the fact that (1) intermarriages would have been rare because Berbers belonged to a tribal endogamous system and often they were in continuous rejection of the domination of these arrivals, who themselves avoided inter-marriage because of their feeling of superiority as invaders and (2) the majority of foreign arrivals generally left the country after their defeat due to the arrival of a new power (Ben Halima et al. 2014). 
Moreover, one of the most important facts in the history of this region is the Arab conquest that, occurred during the $7^{\text {th }}$ century, had led to profound cultural, linguistic and religious changes on North African natives, including islamization and arabization have durably determined the fate of Berbers. The last occupations of North Africa, at the time of colonialism, were those of the Europeans: the Portuguese and the Spanish in Morocco; the French in Morocco, Algeria and Tunisia; Italians in Libya and Ottoman Turks, particularly in Egypt. Thus, North Africa is characterized by an extraordinarily complex history of demographic events, which could have some genetic impact on current genetic profile of North African populations.

The status of the overall ethnic structure of contemporary North African populations (Moroccan, Algerian, Tunisian and Libyan), is relatively similar. According to Ben Halima et al. 2014, 2015, each of these populations is composed of a general (Arab-Berber) Arabic-speaking group (a mixture mainly between Berber and Arab) and some Berber groups who often speak both Berber and Arabic languages. Although these Berber groups are respectively important in Morocco and Algeria and moderate in Libya, they are few and small in Tunisia. Today in Algeria, the Berbers represent 15 to $33 \%$ whose Berber language (Tamazight) is composed of several different dialects, the most important of which are: Kabyle, Chaoui, Mozabite and Touareg, the most indisputable criterion for identifying these people as their Language (Danver 2015; Abdeli and Benhassine 2019).

In recent years, several studies using classical markers (blood types, serum proteins, etc.) were conducted to explore the genetic history of North African populations (e.g., Chaabani and Cox 1988, Bosch et al. 1997; Lefevre-Witier et al. 2006; Coudray et al. 2006; Aouar et al. 2012; Ben Halima et al. 2015). Many other studies were carried out using different molecular markers STR, SNP, mtDNA, Chromosome Y, Chromosome X, etc.) (e.g., Chaabani et al. 1989; Arnaiz-Villena et al. 1995; Côrte -Real et al. 1996 ; Ivanova et al. 1999; Macaulay et al. 1999; Bosch et al. 2000 ; Comas et al. 2000 ; Plaza et al. 2003; Arredi et al. 2004; Bahri et al. 2008, 2014; Robino et al. 2008; Vermeulen et al. 2009; Bekada et al. 2010, 2013, 2015 ; El Moncer et al. 2010; González-Pérez et al. 2010 ; Pereira et al. 2010; Henn et al. 2012; Ben Halima et al. 2014; Triki-Fendri et al. 2013, 2015; Amir et al. 2015 ; Solé-Morata et al. 2017; Badache et al. 2019). 
In addition, several works were done on the genetic characterization of North African populations using the analysis of the HLA gene frequencies. In fact, this highly polymorphic HLA system is very informative for anthropological studies thanks to the patterns of its variation, which could reveal spatial and demographic expansions of the human population that would have occurred in the past. It is also known for its discriminatory force between individuals and populations (due to the high number of alleles for each locus). Moreover, positions between estimated populations based on frequency data for all HLA loci are strongly correlated with geographic distances (Sanchez-Mazas et al. 2011). However, recent studies confirm the natural selection acting on the evolution of HLA polymorphism and show that this selection extends beyond the heterozygous advantage model and has operated from ancient to very recent time scales and has resulted in recent changes in allele frequencies (Lindo et al. 2016; Meyer et al. 2018).

The major purpose of this article is to review the results of the analyses of HLA genes in the different North African populations, to summarize the genetic diversity between the different geographical regions and linguistic groups in North Africa, and to deduce some conclusions on the genetic history of Algerians within the other North African and neighboring populations. Owing to the high number of published works, it is not possible to present all published results and/or conclusions. Therefore, only the more informative ones deduced from the exploration of quite large samples were cited and considered in the discussion. The ambition here was to draw up a provisional state of what is known, in order to serve as a basis for subsequent researchers.

\section{Current status of the genetic differentiation of Algerian population according to HLA system}

In order to present and discuss results and conclusions of selected works on the distribution of HLA genes in Algerians within North Africans and neighboring Mediterranean populations, I have followed three levels of the hierarchy: - genetic characterization of the Algerian population and its affinity with the other North African populations, - genetic relationship between North Africans and Southern Europeans, and - genetic relationship between North African and Middle East populations. 


\section{Genetic affinity between North African populations}

The genetic profile of Algerian population and its relationship with those of the other North African populations were determined by the HLA allele variation in several works (El Sawy et al. 1984; Izaabel et al. 1998; Oumhani et al. 2002; Brick et al. 2006; Galgani et al. 2013; Mahfoudh et al. 2013; Hajjej et al. 2015, 2016, 2017). The kinship analysis, based on phylogenetic tree genetic distances and multidimensional analyses, revealed a strong genetic relationship between different North African groups (the Algerians, the Moroccans of the region of Jadida, the Moroccans Berber, and Tunisians).

This strong genetic relationship between North African populations revealed by analysis of HLA allele variation was also revealed using other powerful classic markers (GM and RH markers) or molecular markers (Alu and Alu/STR compound systems) the analysis of which showed that when wide areas are considered, no significant differences were obtained among North African populations (Coudray et al. 2006; Bahri et al. 2008; El Moncer et al. 2010, Ben Halima et al. 2015). Such genetic homogeneity between North African populations agrees with historic data considering North African populations as having similar origins.

\section{Genetic relationships between North Africans and Southern Europeans}

Extensive scientific research on the genetic diversity of HLA Class I and II alleles has been carried out in populations of Northern Africa and certain populations of the Iberian Peninsula in order to determine the genetic relationships between the ethnic groups of the Iberian Peninsula (Spain) and Berbers, the natives of North Africa (the Paleo-North Africans).

Results of serological and molecular polymorphism studies of the HLA-A, -B, DRB1, -DQA1 and DQB1 alleles in the Algerian and Iberian populations (Bouali et al. 1981; Djoulah et al. 1994; Arnaiz-Villena et al. 1995, 1997, 2002) indicate a genetic link between the populations of the South-Western Europe and that of Algeria. This confirms the evidence that the latter, mainly its Berber component, has a common descent with the Basques and Spaniards, probably reflecting a Neolithic relationship between Iberians and Paleo-North Africans. Similarly, the genetic distance analysis of the HLA DRB1, DQA1 and DQB1 polymorphisms in the population of Morocco 
(Izaabel et al. 1998) showed that the Moroccan population is close to those of the Spain and Algeria.

In addition, the results of the molecular diversity of Class II genes of the HLA system in three populations in Southern Tunisia compared to the entire population Mediterranean region demonstrate a close genetic relationship between populations of Africa and the North-western and South Western Europe, while the populations of the Eastern Mediterranean region are much more differentiated (Abdennaji Guenounou et al. 2006).

Other studies, conducted on Spanish populations (Martinez-Laso et al. 1995, Comas et al. 1998; Sanchez-Velasco et al. 2003), show that allelic frequencies between the Spanish and the Basques do not differ significantly. Comparison with other Mediterranean populations places the Basques and Spaniards closer to the paleo-North African populations than other Europeans. This goes in favor of the Basques being a relative genetic isolate from primitive Iberian/paleo-North African populations.

\section{Genetic relationships between North Africans and Eastern populations}

However, with regard to genetic relations between the North African and Eastern populations (especially the Arab populations of the Middle East), the analysis of haplotypes of the HLA system of the various works (Hajjej et al. 2016, 2015, 2017; Buhler and Sanchez-Mazas 2006), shows a distinction between North Africans (Arabicspeaking and Berber-speaking) and Middle East populations (Arab-Palestinians, Lebanese and Jordanians) despite the depth of Arab incursions and arabization.

Beside these results related particularly to North African and Mediterranean populations, the HLA allele variation was analyzed at the world scale showing high levels of genetic diversity within sub-Saharan Africa and East Asia, and low within Europe, and low genetic differentiations among the three broad continental areas, with no special divergence of Africa (Sanchez-Mazas 2001).

\section{Conclusion}

In this report, after a general overview on the history of the human settlement of North Africa and the ethnic composition of North African populations, I have reviewed published anthropogenic data of HLA allele variation in these populations. The comparison of these data with those found in other world populations, particularly the 
Mediterranean and Middle-Eastern ones, has recapitulated the genetic position of the populations of North Africa (the Maghreb) among the world populations.

The analysis of the HLA genotyping results and the phylogenetic data of the various studies carried out indicate first, a close genetic link between samples from the Algerian population and those from the neighboring North African populations, including Morocco and Tunisia. The North African ancestral genetic structure clearly observed also in each population sample reflects almost the same migratory flow, in other words, they followed the general evolution of Maghreb demographic movements. This homogeneous genetic pattern due to the fact that North Africa was inhabited by Berber groups (the natives of North Africa) shows that North Africa would be considered a separate geographical and ethnic entity in Africa.

Published results also show a genetic relationship between these populations and populations of South-West Europe in particular those of the Basques and Spaniards. This could be proof that the North Africans, mainly its Paleo-North African population (the Berber component), has a common descent with the Basques and the Spaniards, probably reflecting a prehistoric (Epi-paleolithic) relationship between Iberians and Paleo-North African and supporting the theories of flow during the late Neolithic of trans-Gibraltar genes.

However, North African populations are not genetically close to the Arab populations of the Near East. This confirms that despite the expansion of Arabs in the East and arabization, gene flow from the Arab Peninsula and its impact on North African populations was not really significant.

Moreover, the analysis of the genetic diversity of the HLA system in the populations of North West Africa seems to be rather complex and cannot be studied in isolation without referring to the polymorphism of this system among the European populations, Near Eastern populations and Sub-Saharan populations. In this way beside these results related particularly to North African and Mediterranean populations, the HLA allele variation was analyzed at the world scale showing high levels of genetic diversity within sub-Saharan Africa and East Asia, and low within Europe, and low genetic differentiations among the three broad continental areas, with no special divergence of Africa.

Acknowledgements: The author would like to express his gratitude to the participants and the supporting staff in this study for their immense support. 
Conflicts of Interest: The author declares no conflict of interest.

\section{References}

Abdeli A.and Benhassine T. 2019. Paternal lineage of the Berbersn from Aurès in Algeria: Estimate of their genetic variation. Annals of Human Biology 46(2):160-168. DOI: $10.1080 / 03014460.2019 .1602166$

Abdennaji Guenounou B., Yacoubi Loueslati B., Buhler S., Hmida S., Ennafaa H., Khodjet-Elkhil H. et al. 2006. HLA class II genetic diversity in southern Tunisia and the Mediterranean area'. International Journal of Immunogenetics 33: 93-103. DOI: $10.1111 / \mathrm{j} .1744-313 X .2006 .00577 . \mathrm{X}$

Amir N., Sahnoune M., Chikhi L., Atmani D. 2015. STR-based genetic structure of the Berber population of Bejaia (Northern Algeria) and its relationships to various ethnicgroups. Gene 574(1):140-148. DOI:10.1016/j.gene.2015.08.002

Aouar Metri A., Sidi-Yakhlef A., Biémont C., Saïdi M., Chaif O., Ouraghi A. 2012. A genetic study of nine populations from the region of Tlemcen in Western Algeria: a comparative analysis on the Mediterranean scale. Anthropological Science 120 (3) : 209-216. DOI: https://doi.org/10.1537/ase.120618

Arredi B., Poloni ES., Paracchini S., Zerjal T., Fathallah DM., Makrelouf M., Pascali VL.,Novelletto A., Tyler-Smith C. 2004. A predominantly neolithic origin for Y chromosomal DNA variation in North Africa. Am J Hum Genet 75(2):338-345. DOI: $\underline{10.1086 / 423147}$

Arnaiz-Villena A., Gomez-Casado E.,Martinez-Laso J.2002. Population genetic relationships between Mediterranean populations determined by HLA allele distribution and a historic Perspective. Tissue Antigens 60: 111-121.

DOI: $10.1034 / \mathrm{j} .1399-0039.2002 .600201 . \mathrm{x}$

Arnaiz-Villena A., Martinez-Laso J., Gomez-Casado E., Díaz-Campos N., Santos P., Martinho F., Breda-Coimbra H. 1997.Relatedness among Basques, Portuguese, Spaniards, and Algerians studied by HLA allelic frequencies and haplotypes. Immunogenetics 47: 37-43. DOI: https://doi.org/10.1007/s002510050324

Arnaiz-Villena A. Benmamar D., Alvarez M., Diaz-Campos N., Varela P., GomezCasado E., Martinez-Laso J. 1995. HLA Allele and Haplotype Frequencies in Algerians: Relatedness to Spaniards and Basques. Human Immunology 43: 259-268. DOI: https://doi.org/10.1016/0198-8859(95)00024-X

Badache H., Boussetta S., Benammar Elgaaeid A., Cherni L. \& Khodjet El-khil H. 2019. Investigation of the genetic structure of Kabyle and Chaouia Algerian populations through the polymorphism of Alu insertion markers. Annals of Human Biology 46 (2): 150-159. DOI: $10.1080 / 03014460.2019 .1588994$ 
Bahri R., Esteban E., Moral P., Chaabani H. 2008. New insights into the genetic history of Tunisians: data from Alu insertion and Apolipoprotein E gene polymorphisms. Ann Hum Biol 35: 22-33. DOI:10.1080/03014460701753729.

Bahri R., Esteban E., Ben Halima A., Moral P., ChaabaniH. 2014. Distinctive genetic signatures of Alu/STR compound systems revealed from Mediterranean and Middle East population Analyses. Anthropological Science 122: 81-88.

DOI:10.1537/ase.140602

Bekada A., Benhamamouch S., Boudjema A., Fodil M, Menegon S., Torre C., Robino C.2010. Analysis of $21 \mathrm{X}$-chromosomal STRs in an Algerian population sample. Int J Legal Med 124(4): 287-294. DOI:10.1007/s00414-009-0397-9.

Bekada A., Fregel R., Cabrera VM., Larruga JM., Pestano J., Benhamamouch S., González AM. 2013. Introducing the Algerian mitochondrial DNA and Y-chromosome profiles into the North African landscape. PLoS One 8(2):e56775.

DOI: https://doi.org/10.1371/journal.pone.0056775

Bekada A., Arauna LR., Deba T., Calafell F., Benhamamouch S., Comas D. 2015. Geneticheterogeneity in Algerian human populations. PloS One 10(9):e0138453. DOI: $10.1371 /$ journal.pone.0138453

Ben Halima A., Bahri R., Esteban E., Ben Aribia M.H., Moral P and Chaabani H. 2014. Ethnic composition and genetic differentiation of the Libyan population: insights on Alu polymorphisms. Annals of Human Biology 41(3): 229-237.

DOI: https://doi.org/10.3109/03014460.2013.850112

Ben Halima A., Bahri R., Esteban E., Moral P and Chaabani H. 2015. Variation of Rhesus Haplotype Frequencies in North Africans and in Worldwide Population Analyses. Int J Hum Genet 15 (1):21-31. DOI:

https://doi.org/10.1080/09723757.2015.11886247

Bosch E., Calafell F., Pérez-Lezaun A., Comas D, Mateu E., Bertranpetit J. 1997.Population history of North Africa: evidence from classical genetic markers. Hum Biol 69(3): 295-311.

Bosch E., Calafell F., Pérez-Lezaun A., Clarimón J., Comas D., Mateu E., MartínezAriasR., Morera B., Brakez Z., Akhayat O. et al. 2000. Genetic structure of North-West Africa revealed by STR analysis. Eur J Hum Genet 8(5):360-366.

DOI: https://doi.org/10.1038/sj.ejhg.5200464.

Bouali M.,Dehay C.,BenajamA.,PoirierJ. C.,DegosL.,Marcelli-BargeA.1981. HLA-A, $\mathrm{B}, \mathrm{C}, \mathrm{Bf}$ and glyoxalase I polymorphisms in a sample of the kabyle population (Algeria). Tissue Antigens 17: 501-506.

DOI: https://doi.org/10.1111/j.1399-0039.1981.tb00737.x

Brett M. and Fentress E. 1996. The Berbers. Oxford: Blackwell 
Brick C., Bennani N., Atouf O., Essakalli M. 2006. 'HLA-A, -B, -DR and -DQ allele and haplotype frequencies in the Moroccan population: a general population study'. Transfusion Clinique et Biologique 13: 346-352. DOI: 10.1016/j.tracli.2006.12.003

Buhler S., Sanchez-Mazas A., 2006. De l'Europe à l'Inde : structure génétique et diversité des populations de part et d'autre de leurs frontières géographiques et culturelles. Antropo 11: 249 - 259.

Camps G. 1980. Les Berbères ; Mémoire et identité. Paris : Errance.

Camps G. 1981. L'origine des berbères. Islam : société et communauté. Anthropologies du Mahgreb, sous la direction de Ernest Gellner. Les Cahiers C.R.E.S.M, Éditions CNRS, Paris.

Chaabani H. and Cox W. 1988. Genetic characterization and origin of Tunisian Berbers. Human heredity 38 (5): 308-316.

Chaabani H., Bech-Hansen N.T., Cox D.W. 1989. Restriction fragment length polymorphisms associated with immunoglobulin heavy chain gamma genes in Tunisians. Hum Genet 73: 110-113.

Comas D., Mateu E., Calafell F., Pérez-Lezaun A., Bosch E., Martínez-Arias R., Bertranpetit V. 1998. HLA class I and class II DNA typing and the origin of Basques. Tissue Antigens 51: 30-40. DOI: https://doi.org/10.1111/j.1399-0039.1998.tb02944.X

Comas D., Calafell F., Benchemsi N., Helal A., Lefranc G., Stoneking M., Batzer MA.,Bertranpetit J., Sajantila A. 2000. Alu insertion polymorphisms in NW Africa and the Iberian Peninsula: evidence for a strong genetic boundary through the Gibraltar Straits. Hum Genet 107(4): 312-319. DOI:10.1007/s004390000370

Côrte-Real HBSM., Macaulay VA., Richards MB., Hariti G., Issad MS., CambonThomsen A., Papiha S., Bertranpetit J., Sykes BC. 1996. Genetic diversity in the Iberian Peninsula determined from mitochondrial sequence analysis. Ann Hum Genet.60(4):331-350. DOI:10.1111/j.1469-1809.1996.tb01196.x

Coudray C. Olivieri A., Achilli A., Pala M., Melhaoui M., Cherkaoui M., et al. 2009. The Complex and Diversified Mitochondrial Gene Pool of Berber Populations. Annals of Human Genetics 73: 196-214. DOI: 10.1111/j.1469-1809.2008.00493.x

Coudray C., Guitard E., Gibert M., Sevin A., Larrouy G., Dugoujon J.M. 2006. Diversité génétique (allotypie GM et STRs) des populations Berbères et peuplement du nord de l'Afrique. Antropo 11: 75-84.

Danver SL. 2015. Native peoples of the world: an Encylopedia of groups, cultures and contemporary issues. London: Routledge.

Djoulah S., Sanchez-Mazas A., Khalil I., Benhamamouch S., Degos L., Deschamps I., Hors J. 1994. HLA-DRB1, DQAl and DQB1 DNA polymorphisms in healthy Algerian and genetic relationships with other populations. Tissue Antigens 43: 102-109.

DOI: https://doi.org/10.1111/j.1399-0039.1994.tb02308.x 
El Moncer W., Esteban E., Bahri R., Gaya'-Vidal M., Carreras-Torres R., Athanasiadis G., Moral P.and Chaabani H. 2010. Mixed origin of the current Tunisian population from the analysis of Alu and Alu/STR compound systems. Journal of Human Genetics 55: 827-833. DOI: https://doi.org/10.1038/jhg.2010.120.

El sawy M. et al. 1984. HLA-A, -B and -C specificities in a sample of the Nile Delta population, Egypt. Tissue Antigens 24: 206-208.

Galgani A. Mancino G., Martínez-Labarga C., Cicconi R., Mattei M., Amicosante M.,et al. 2013. HLA-A, -B and -DRB1 allele frequencies in Cyrenaica population (Libya) and genetic relationships with other populations. Human Immunology 74: 52-59.

DOI: $10.1016 /$ j.humimm.2012.10.001

González-Pérez E., Esteban E., Via M., Gayà-Vidal M., Athanasiadis G., Dugoujon JM.,Luna F., Mesa MS., Fuster V., Kandil M, et al. 2010. Population relationships in the Mediterranean revealed by autosomal genetic data (Alu and Alu/STR compound systems). Am J Phys Anthropol 141(3): 430-439. DOI:10.1002/ajpa.21161.

Hajjej A., Almawi W.Y., Hattab L., Hmida S. 2017. Anthropological analysis of Tunisian populations as inferred from HLA class I and class II genetic diversity: ametaanalysis. Immunology Letters 185:12-26.

DOI: http://dx.doi.org/10.1016/j.imlet.2017.02.014.

Hajjej A. Almawi W.Y., Hattab L., El-Gaaied A., Hmidaa S. 2016. The investigation of the origin of Southern Tunisians using HLA genes. Journal of Human Genetics 1-11. DOI: $\underline{10.1038 / \text { jhg. } 2016.146}$

Hajjej A. Almawi W.Y., Hattab L., El-Gaaied A., Hmidaa S. 2015. HLA Class I and Class II Alleles and Haplotypes Confirm the Berber Origin of the Present Day Tunisian Population. PLOS ONE 10(8): e0136909. DOI: 10.1371/journal.pone.0136909

Henn BM., Botigué LR., Gravel S., Wang W., Brisbin A., Byrnes JK., Fadhlaoui-Zid K.,Zalloua PA., Moreno-Estrada A., Bertranpetit J. et al. 2012. Genomic ancestry of North Africans supports back-to-Africa migrations. PLoS Genet 8(1):e1002397. DOI: https://doi.org/10.1371/journal.pgen.1002397

Ivanova R., Astrinidis A., Djoulah S., Lepage V., Wijnen E., Hors J., Charron D. 1999. Mitochondrial DNA polymorphisms of a west Algerian population (Oran region). Biomed Pharmacother 53(8): 386-392. DOI:10.1016/s0753-3322(99)80110-3

Izaabel H., Garchon H.-J. Caillat-Zucman S., Beaurain G., Akhayat O., Bach J.F., Sanchez- Mazas A. 1998. HLA class II DNA polymorphism in a Moroccan population from the Souss, Agadir area. Tissue Antigens 51: 106-110.

DOI: https://doi.org/10.1111/j.1399-0039.1998.tb02954.x

Lefevre-Witier P., Aireche H., Benabadji M., Darlu P, Melvin K., Sevin A., Crawford MH. 2006. Genetic structure of Algerian populations. Am J Hum Biol 18(4):492-501. DOI: $\underline{10.1002 / a j h b .20511}$ 
Lindo J., Huerta-Sánchez E., Nakagome S. et al. 2016. A time transect of exomes from a Native American population before and after European contact. Nat Commun 7: 1315. DOI: $10.1038 /$ ncomms 13175 (2016).

Macaulay V., Richards M., Hickey E., Vega E., Cruciani F., Guida V., Scozzari R., Bonné-Tamir B., Sykes B., Torroni A. 1999. The emerging tree of West Eurasian mtDNAs: asynthesis of control-region sequences and RFLPs. Am J Hum Genet 64(1):232-249. DOI: $10.1086 / 302204$

Mahfoudh N., Ayadi I., Kamoun A., Ammar R., Mallek B., Maaledj L., et al. 2013. Analysis of HLA-A, -B, -C, -DR, -DQ polymorphisms in the South Tunisian population and a comparison with other populations. Annals of Human Biology 40 (1): 41-47. DOI: https://doi.org/10.3109/03014460.2012.734334

Martinez-Laso J., De JuanD., Martinez-QuilesN., Gomez-Casado E., Cuadrado E., Arnaiz-Villena A. 1995. The contribution of the HLA-A, -B, -C and -DR, -DQ DNA typing to the study of the origins of Spaniards and Basques. Tissue Antigens 45: 237245. DOI: https://doi.org/10.1111/j.1399-0039.1995.tb02446.x

Meyer B.S., Hablützel P. I., Roose A.K, Hofmann M.J., Salzburger W., Raeymaekers J-AM. 2018. Alignment of genetic variants of the MHC class II loci of East African cichlids. PANGAEA. DOI : https://doi.org/10.1594/PANGAEA.893876.

Pereira L., Silva NM., Franco-Duarte R., Fernandes V., Pereira JB., Costa MD., Martins H., Soares P., Behar DM., Richards MB., et al. 2010. Population expansion in the North African late Pleistocene signalled by mitochondrial DNA haplogroup U6. BMC Evol Biol 10(1): 390. DOI: https://doi.org/10.1186/1471-2148-10-390

Plaza S., Calafell F., Helal A., Bouzerna N., Lefranc G., Bertranpetit J., Comas D. 2003. Joining the pillars of Hercules: mtDNA sequences show multidirectional gene flow in the western Mediterranean. Ann Hum Genet. 67(4): 312-328.

DOI:10.1046/j.1469-1809.2003.00039.x

Oumhani K.,Canossi A., Piancatelli D., Di Rocco M., Del Beato T., Liberatore G., et al. 2000. Sequence-Based Analysis of the HLA-DRB1Polymorphism in Metalsa Berber and Chaouya Arabic-Speaking Groups From Morocco. Human Immunology 63: 129138. DOI: $10.1016 / \mathrm{S} 0198-8859(01) 00370-6$

Robino C., Crobu F., Di Gaetano C., Bekada A., Benhamamouch S., Cerutti N., Piazza A., Inturri S., Torre C. 2008. Analysis of Y-chromosomal SNP haplogroups and STR haplotypes in an Algerian population sample. Int J Legal Med. 122(3): 251-255. DOI:10.1007/s00414-007-0203-5

Sanchez-Mazas A., Fernandez-Viña M., Middleton D., Hollenbach J.A., Buhler S., Di D., Rajalingam R., Dugoujon J-M, et al. 2011. Immunogenetics as a tool in anthropological studies. Immunlogy 133 (2):143-164. DOI: 10.1111/j.13652567.2011.03438.x 
Sanchez-Mazas A., 2001. African Diversity from the HLA Point of View: Influence of Genetic Drift, Geography, Linguistics, and Natural Selection. Human Immunology 62, 937-948. DOI: https://doi.org/10.1016/S0198-8859(01)00293-2

Sanchez-Velasco P., Gomez-Casado E., Martinez-Laso J., MoscosoJ., Zamora J., Lowy E., et al. 2003. HLA alleles in isolated populations from North Spain: Origin of the Basques and the ancient Iberians. Tissue Antigens 61: 384-392.

DOI: https://doi.org/10.1034/j.1399-0039.2003.00041.x

Solé-Morata N., García-Fernández C., Urasin V., Bekada A., Fadhlaoui-Zid K., Zalloua P., Comas D., Calafell F. 2017. Whole Y-chromosome sequences reveal an extremelyrecent origin of the most common North African paternal lineage E-M183 (M81). Sci Rep 7(1):15941. DOI : https://doi.org/10.1038/s41598-017-16271-y

Triki-Fendri S., Sanchez-Diz P., Rey-Gonzalez D., Ayadi I., Carracedo A., Rebai A. 2015. Paternal lineages in Libya inferred from Y chromosome haplogroups. American Journal of Physical Anthropology 175 (2): 242-251. DOI:10.1002/ajpa.22705

Triki-Fendri S., Sanchez-Diz P., Rey-Gonzalez D., Ayadi I., Alfadhli S., Rebai A., Carracedo A. 2013. Population genetics of 17 Y-STR markers in West Libya (Tripoli region). Forensic Sci Int: Genetics 7: 59-61. DOI:10.1016/j.fsigen.2013.02.002

Vermeulen M., Wollstein A., van der Gaag K., Lao O., Xue Y., Wang Q., Roewer L., Knoblauch H., Tyler-Smith C., de Knijff P., et al. 2009. Improving global and regional resolution of male lineage differentiation by simple single-copy Y-chromosomal short tandem repeat polymorphisms. Forensic Sci Int Genet 3(4): 205-213.

DOI:10.1016/j.fsigen.2009.01.009

To cite this article:

Moussouni A. 2020. Review on the Genetic History of Algerians within North African Populations from the HLA Point of View

International Journal of Modern Anthropology. 2 (13): 164 - 176

DOI: http://dx.doi.org/10.4314/ijma.v2i13.6

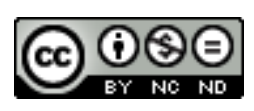

This article, as all articles published in this journal, is under The Creative Commons Attribution: Attribution-NonCommercial-NoDerivatives 4.0 International (CC BY-NC-ND 4.0). https://creativecommons.org/licenses/by-nc-nd/4.0/ 